Висновки. Отже, законодавство Румунії у сфрері освіти забезпечує рівні права доступу до всіх рівнів і фрорм початкової, середньої та вищої освіти, а також на навчання протягом усього життя без будь-яких форм дискримінації як громадянам Румунії, так і громадянам інших країн-членів Європейського Союзу, держав, що належать до Європейського економічного простору та Швейцарської Конфедерації. Трансформаційні процеси, завдяки яким система освіти Румунії зазнала таких істотних змін, підвищили її доступність і якість, а підготовка фахівців відповідає провідним європейським вимогам сьогодення.

Список використаних джерел

1. Заскалєта С. Г. Тенденції професійної підготовки фахівців аграрної галузі в країнах Європейського Союзу : монографрія / С. Г. Заскалєта ; за ред. С. О. Сисоєвої. - Миколаїв : Іліон, 2013.

2. Зязюн І. А. Філософія педагогічної діяльності у професійній освіті / І. А. Зязюн // Діалог культур: Україна у світовому контексті: фрілософрія освіти : зб. наук. пр. / Ін-т педагогіки і психології проф. освіти АПН України, Львів. наук.- практ. центр. - Л. : Сполом, 2002. - Вип. 8. - С. 4-14.
3. Пальчук М. Модель професійної освіти й навчання в Румунії - п'ятий етап європейської інтеграції / М. Пальчук // Наук. вісн. Миколаїв. держ. ун-ту імені В. О. Сухомлинського. Серія: Педагогічні науки. - 2011. Вип. 1.33. - С. 169-175.

4. Сучасні моделі професійної освіти і навчання в країнах Європейського Союзу: порівняльний досвід : монографія / В. О. Радкевич й ін. / за заг. Ред. В. О. Радкевич. - К. : ІПТО НАПН України, 2018.

References

1. Zaskalieta S. H. Tendentsii profesiinoi pidhotovky fakhivtsiv ahrarnoi haluzi v krainakh Yevropeiskoho Soiuzu : monohrafiia / S. H. Zaskalieta ; za red. S. O. Sysoievoi. - Mykolaiv : Ilion, 2013.

2. Ziaziun I. A. Filosofiia pedahohichnoi diialnosti u profesiinii osviti / I. A Ziaziun // Dialoh kultur: Ukraina u svitovomu konteksti: filosofiia osvity : zb. nauk. pr. / In-t pedahohiky i psykholohii prof. osvity APN Ukrainy, Lviv. nauk.prakt. tsentr. - Lviv : Spolom, 2002. - Vyp. 8. - S. 4-14.

3. Palchuk M. Model profesiinoi osvity y navchannia v Rumunii - piatyi etap yevropeiskoi intehratsii / M. Palchuk // Naukovyi visnyk Mykolaivskoho derzhavnoho universytetu imeni V. O. Sukhomlynskoho. Seriia: Pedahohichni nauky. - 2011. - Vyp. 1.33. - S. 169-175.

4. Suchasni modeli profesiinoi osvity i navchannia $v$ krainakh Yevropeiskoho Soiuzu: porivnialnyi dosvid: monohrafiia / V. O. Radkevych et al. / za zah. red. V. O. Radkevych. - Kyiv : IPTO NAPN Ukrainy, 2018.

Надійшла до редколегії 11.02.20

K. Tulin, post-graduate student,

Taras Shevchenko National University of Kyiv, Kyiv, Ukraine,

\title{
LEGISLATIVE DIMENSION OF THE FUNCTIONING OF ROMANIA'S EDUCATION SYSTEM
}

The article is a study of the main legal documents governing the functioning of the Romanian education system. The documents that create the regulatory and legal field of education are identified. It is noted that the Strategy for the Development of Vocational Education in Romania for 20162020 provides for four main strategic goals and discloses each of them. The main provisions of some articles of the Law of Romania "On National Education", №1/2011 of January 5, 2011 are considered. Attention is paid to the issues of education of national minorities and the organization of their education in the education system. It is noted that the Law on National Education, 1/2011 of January 5, 2011 establishes the possibility of teaching in educational institutions in the languages of national minorities, but the study of Romanian language and Romanian literature is in the state language. It is determined that since the beginning of the first private universities and the beginning of a rapid increase in the number of higher education institutions, faculties and research programs/specializations, a law has been adopted establishing the National Council for Academic Evaluation and Accreditation. in 2005 it was replaced by the Agency for Quality Assurance in Higher Education (ARACIS). The functions assigned to ARACIS are considered and the steps of the accreditation procedure are revealed. It is noted that according to Article 17 of the Law "On Approval of the Government Emergency Decree №75/2005 on Quality Assurance in Education" one of the tasks of ARACIS is to develop a Code of Professional Ethics for experts in assessment and accreditation. It is stated that one of the important functions of ARACIS is the maintenance of the National Register of Experts Conducting the Accreditation Procedure and describes the list of data entered into it.

Keywords: education system, Romania, legislation, education, national minorities.

УДК 378.14:613.7

DOI: https://doi.org/10.17721/2415-3699.2020.12.15

І. Усатова, канд. пед. наук, В. Ткаченко, канд. пед. наук, доц., А. Ведмедюк, канд. пед. наук, доц. Черкаський національний університет імені Богдана Хмельницького, Черкаси

\section{ПОБУДОВА ЗМІСТУ ПІДГОТОВКИ МАЙБУТНІХ ФАХІВЦІВ ДО РЕАЛІЗАЦІї ЗДОРОВ'ЯЗБЕРЕЖУВАЛЬНИХ ТЕХНОЛОГІЙ}

Розкрито шляхи удосконалення системи професійної освіти з метою підготовки майбутнього фахівця до практичного втілення ідеї здоров'язбереження нації на всіх етапах освітньої діяльності; обґрунтовано загальну структуру системи забезпечення якості освіти на рівні закладу вищої освіти; визначено ефективне використання загальнодидактичних принципів; з'ясовано нові підходи до розроблення змісту, форм і методів професійної підготовки фахівців нової формації; досліджено зміст професійної підготовки майбутніх фахівців, що охоплює сукупність знань, умінь і навичок, володіння якими дає змогу працювати за обраним видом професії; окреслено сукупність принципів, функцій і чинників, що впливають на зміст підготовки, поданий у навчальних планах і програмах вищих освітніх закладів. Подано аналіз структури підготовки майбутніх фахівців у закладах вищої освіти, що прогнозує оволодіння комплексом професійно-особистісних компонентів майбутнього спеціаліста. З'ясовано особливості підготовки майбутніх фахівців до реалізації здоров'язбережувальних технологій за пропонованими навчальними закладами освітньо-професійними програмами. Показано видове різноманіття виробничої та науково-дослідницької практик, названо форми та методи навчання.

Охарактеризовано зміст професійної підготовки майбутніх фахівців, окреслено передумови створення концепції формування готовності майбутніх фахівців до здійснення інноваційної діяльності; сформульовано умови ефективного використання здоров'язбережувальних технологій, висвітлено сутнісні характеристики й етапи підготовки майбутніх фрахівців у закладах освіти; обґрунтовано основні положення, дотримання яких забезпечує підготовку фахівців нової формації до реалізації здоров'язбережувальних технологій. Зазначено, що здатність до самоорганізації є основою успішної професійної діяльності майбутнього фахівця та зауважено навчальні дисципліни програм підготовки вітчизняних закладів вищої освіти, вивчення яких сприяє формуванню компетентності самоорганізації. Розкрито сутність проблеми, що розглядається та технологію їі розв'язання.

Ключові слова: майбутній фахівець, загальнодидактичні принципи, здоров'язбережувальні технології.

Постановка проблеми. На шляху вступу України до глобалізованого економічного простору дедалі важливішим $є$ процес підготовки висококваліфікованих фахівців. Очевидним $є$ фракт, що модернізація економіки України неможлива без підготовки молодих кадрів із відповідним рівнем кваліфікації, оскільки саме вони здатні гнучко реагувати на нововведення, генерувати принципово нові ідеї, впроваджувати новітні технології, обслуговувати 
технологічно оновлене устаткування, адаптоване до сучасних вимог інноваційного суспільства.

Сучасне суспільство зазнає кардинальних змін, зокрема відбувається реформування системи вищої освіти України. Ці проблеми потребують особливої уваги, постійної модернізації змісту вищої професійної освіти, досягнення варіативності та гнучкості навчальних планів і програм, їхньої швидкої та вчасної реакції на запити суспільства.

У нинішньому контексті професійна підготовка майбутніх фахівців до реалізації здоров'язбережувальних технологій повинна мати випереджальний характер, зважати на багаторівневість вищої професійної освіти.

Необхідність в інноваційній спрямованості педагогічної діяльності, на думку О. Дубасенюк, зумовлена такими обставинами: соціально-економічні перетворення у суспільстві; науково-технічний процес, що вмотивовує необхідність оновлення системи вищої освіти, методології й технології організації навчально-виховного процесу в закладах вищої освіти; посилення гуманітаризації змісту освіти; зміна обсягу та складу навчальних дисциплін, уведення нових навчальних предметів; використання нових організаційних форм і технологій навчання; застосування педагогічних новацій $[4$, с. 4].

І. Гринченко наголошує, що відповідності змісту вищої освіти вимогам соціального замовлення досягають завдяки розширенню структури, змісту навчання [2, с. 76]. В. Шмельов зазначає, що технологія фрормування наукового знання починається з пізнання змісту та процесу побудови навчального матеріалу, рівня засвоєння студентами необхідних знань, визначення здібностей та особливостей складу учнів. Автор зауважує, що, трансформуючи зміст навчального матеріалу в навчальний предмет, необхідно інтегрувати професійні вміння і зміст навчального матеріалу $[14$, с. 16$]$.

Згідно з академічним тлумачним словником української мови, зміст - це суть, внутрішня особливість чого-небудь; розумна основа, мета, призначення чого-небудь [8]. На думку С. Клепка, визначення змісту освіти є важливим інтеграційним процесом у системі сучасних знань, які характеризують світ знань, необхідних для успішності особистості; визначення змісту освіти натомість впливає на процеси організації наукового знання [9, с. 28].

Беручи до уваги дослідження І. Зязюна щодо окреслення змісту педагогічних знань і С. Ніколаєнко, які зазначають, що для формування змісту педагогічних знань майбутнім фахівцям потрібні такі знання: методологічні (знання загальних принципів вивчення педагогічних явищ, закономірностей соціалізації навчання та виховання); теоретичні (знання цілей, принципів змісту методів і форм педагогічної діяльності, закономірностей формування й розвитку особистості дитини); методичні (знання основ методики навчання і виховання); технологічні (знання способів і прийомів навчання та виховання) [12, с. 284].

Як слушно зауважує О. Красовська, основою для відбору змісту навчального матеріалу $є$ принципи, які $€$ не вихідним пунктом дослідження, а його заключним результатом. На думку дослідниці, принцип - це інструментальне вираження педагогічної концепції, представлене в категоріях діяльності, методичне вираження пізнаних законів і закономірностей, знання про цілі, сутність, зміст, структуру навчання, виражене у формі, яка дає змогу використовувати їх як регулятивні норми практики [10, с. 29].

Водночас у побудові змісту освіти майбутніх фахівців до реалізації здоров'язбережувальних технологій існують суперечності: між значущістю здоров'язбережувальних технологій для педагогічної роботи та браком теоретико-методичного підґрунтя у процесі професійної освіти; між орієнтацією на нові моделі навчально-виховного процесу у вищій школі й неналежним рівнем опрацювання теоретичних, методичних засад і педагогічних умов, а також недостатнім програмно-методичним і технологічним забезпеченням. Необхідність розв'язання цих суперечностей потребує переосмислення цілей, завдань і змісту підготовки майбутніх фахівців до реалізації здоров'язбережувальних технологій відповідно до вимог сучасної освіти.

Аналіз останніх досліджень і публікацій. Проблему побудови змісту сучасної системи розвитку освіти інноваційного типу вивчали вітчизняні й зарубіжні дослідники: А. Алексюк, Ю. Бабанський, Дж. Гарднер, М. Дичківська, Л. Ланда, 3. Петрасинський, І. Підласий, С. Поляков, Г. Селевко, П. Уайтфілд Л. Штефан та ін. Учені довели, що досягнути ефективності навчально-виховного процесу можна через дотримання певної системи дидактичних принципів. Наголосимо, що винятково значущим для майбутнього фрахівця $є$ вміння ефективно використовувати загальнодидактичні принципи (науковості освіти й навчання; єдності теорії і практики, освіти й навчання; систематичності й послідовності; розвивального та виховного характеру навчання; доступності; структурної єдності предметного та процесуального аспектів змісту освіти; взаємозв'язку змісту, фоорм і методів навчання); специфрічні принципи формування змісту професійної підготовки (узгодженість змісту освіти з цілями підготовки майбутніх фахівців, а також основними видами професійної діяльності фахівців у ході навчання; принципи випереджального (прогностичного) характеру змісту освіти; принципи врахування закономірностей професійного становлення.

Ураховуючи це, можна визначити мету та завдання дослідження. Вона полягає у проведенні аналізу шляхів реформування й обґрунтуванні напрямів модернізації змісту підготовки майбутніх фахівців до реалізації здоров'язбережувальних технологій.

Викладення основного матеріалу. На наш погляд, традиційний формат побудови навчального процесу ускладнює фрормування високого рівня фахової компетентності і професійно значущих якостей майбутнього фахівця.

В "Українському педагогічному словнику" зазначено, що "зміст освіти випливає з її основної функції - прилучити молодь до загальнолюдських і національних цінностей; це - система наукових знань про природу, суспільство, людське мислення, практичних вмінь і навичок i способів діяльності, досвіду творчої діяльності, світоглядних, моральних, естетичних ідей та відповідної поведінки, якими повинен оволодіти учень у процесі навчання. Автор зазначає, що зміст освіти повинен спрямовуватися на досягнення основної мети виховання - формування гармонійно розвиненої, суспільно активної особистості - громадянина України; зміст освіти повинен будуватися на науковій основі" [13, с. 137].

Як слушно зауважує С. Гончаренко, на зміст освіти впливають об'єктивні чинники, які зумовлюють потреби суспільства в розвитку робочої сили; розвиток науки й техніки, супроводжуваний появою нових ідей, теорій і докорінними змінами в техніці й технології, і суб'єктивні чинники, що розкривають політику керівних сил суспільства й методологічні позиції вчених [13, с. 137]. Систему професійної підготовки майбутніх фахівців потрібно вибудовувати на усталених принципах безперервності освіти, її фундаменталізації, інтегративності, гуманізації тощо [13, с. 108].

Отже, зміст професійної підготовки майбутніх фахівців охоплює сукупність знань, умінь і навичок, володіння якими дає змогу працювати за обраним видом 
профресії, а також сукупність принципів, функцій і чинників, що впливають на зміст підготовки, поданий у навчальних планах і програмах закладів вищої освіти. Структура підготовки в закладах вищої освіти прогнозує оволодіння комплексом професійно-особистісних компонентів майбутнього фахівця.

Зміст професійної підготовки майбутніх фрахівців має бути структурно-функціональним, для цього потрібно неодмінно зважати на характер і потреби соціального замовлення щодо підготовки висококваліфікованих і конкурентоспроможних спеціалістів, окреслювати мету й завдання майбутньої професійної діяльності, принципи та підходи науково-методичного забезпечення процесу навчання студентів, які, на наше переконання, взаємопов'язані та взаємозалежні, оскільки, доповнюючи один одного, утворюють цілісну структурну систему змісту професійної підготовки майбутніх фахівців. Г. Остапенко, О. Циганок, С. Жесткова доречно наголошують, що педагогічні умови мають віддзеркалювати структуру підготовки майбутніх фахівців в умовах фахового навчання у вищому освітньому закладі [6, с. 80].

Отже, умовою формування належного рівня профресійної підготовки майбутніх фахівців вважаємо інтеграцію теоретичної та практичної професійної підготовки студентів шляхом модернізації змісту, форм і методів навчання щодо професійного становлення майбутнього фахівця-професіонала в реалізації здоров'язбережувальних технологій.

Організацію навчального процесу в межах освітньокваліфрікаційної підготовки майбутніх фрахівців регламентує, зокрема, навчальний план. "Це нормативний документ вищого навчального закладу, який складається на підставі освітньо-професійної програми та структурнологічної схеми підготовки і визначає перелік та обсяг нормативних і вибіркових навчальних дисциплін, послідовність їхнього вивчення, конкретні фрорми проведення навчальних занять та їх обсяг, графрік навчального процесу, форми та засоби проведення поточного і підсумкового контролю" [3, с. 274].

Як стверджують Л. Дольнікова, Л. Цубов, "у сучасному закладі вищої освіти організація навчального процесу відбувається за діалектичного відмирання застарілого і народження нового, що вимагає наповнення новим змістом начальних програм як нормативних, так і вибіркових дисциплін навчальних планів, готовності закладів вищої освіти створити умови підготовки і формування компетентного випускника, особлива роль під час підготовки якого належить фундаментальній підготовці" [3, с. 274].

Конкретними шляхами реорганізації змісту освіти, характерними для сучасних освітніх реформ у більшості країн є: кількісне зростання навчального часу для вивчення дисципліни, так і структурною перебудовою програм курсу з включенням нових наукових досягнень, наданням програмам якостей гнучкості, відкритості, варіативності; посилення уваги до вивчення іноземних мов, зумовлене активізацією глобалізаційних тенденцій. Вивчення іноземної мови розглядається як засіб посилення конкурентоздатності особистості на ринку праці, так і як засіб активізації міжкультурного спілкування та співробітництва [7, с. 148-149].

Зміст освітньо-професійних програм підготовки фрахівців формується на основі встановлених компетентностей (загальних і спеціальних (фахових, предметних)) i результатів навчання. На магістерському рівні надається поглиблена підготовка із загального та професійного циклів, формується готовність і відповідні компетентності для виконання виробничих завдань на основі якісно нових знань і науки. Метою навчання в магістратурі
$€$ підготовка до педагогічно-професійної та наукової діяльності. Зміст кожної навчальної дисципліни циклів загальної та професійної підготовки має формуватися з урахуванням наукової галузі знання, вимог професійної діяльності, безперервної самоосвіти і професійного саморозвитку майбутнього фахівця та проєктуватися на майбутню професійну діяльність і розвиток загальних і професійних компетентностей. Основна мета циклу загальної підготовки - це формування загальних компетентностей фрахівця. Магістр повинен бути широко ерудованим фахівцем, володіти фундаментальною науковою базою, що дозволяє йому орієнтуватися в комплексі світоглядних проблем сучасної науки, опанувати логіку розвитку наукового знання, психологію наукової творчості, опрацювати методологію досліджень [7, с. 189].

Зауважимо, що в навчальних закладах України існує проблема вибіркових дисциплін. Найперше, контент вибіркових дисциплін обумовлений ресурсами фракультету чи інституту, викладається в конкретному семестрі й обмежений визначеною кількістю студентів, що, насправді, не $є$ свідченням реалізації студентами вибору. Широко використовуваними у процесі підготовки майбутніх викладачів вищої школи такі організаційні форми навчання: проблемні лекції, лекції-дискусії, практичні заняття, стажування магістрантів у закладах вищої освіти, самостійна робота (виконання творчих завдань, розробка проєктів робочих програм, конспектів різних видів занять, аналіз науково-методичної літератури й нормативних документів), курсове проєктування, науково-дослідна робота. Засвоєння теоретичних знань і формування практичних умінь у процесі магістерської підготовки майбутніх викладачів вищої школи у вітчизняних закладах вищої освіти забезпечується методами роботи, які розвивають мислення, формують практичні уміння й досвід творчої діяльності. Із-поміж таких: лекційний метод (у різних його проявах); дискусія; методи контекстного навчання, практико орієнтоване навчання, методи інтерактивного навчання; міні-тренінги; портфоліо, кейс-метод, презентації та ін. [7, с. 216].

Н. Мирончук зазначає, що "у динамічних і часто непередбачуваних умовах професійних реалій сучасний фрахівець вищої школи повинен мати сформовані на належному рівні уміння взаємодіяти у нестандартних ситуаціях, критично мислити, працювати з різними джерелами інформації, обирати ефективні способи поведінки в конкурентному середовищі, бути здатним до неперервної самоосвіти, самоудосконалення, розвитку професійної кваліфікації, пошуку і реалізації нових, ефективних форм організації професійної освіти та професійної діяльності" [11, с. 108]. Автор стверджує, що "такі вимоги актуалізують потребу самоорганізації суб'єктів освіти як інваріанту цілісного процесу організації професійної освіти і професійної діяльності. Відтак із-поміж загальних компетентностей майбутніх викладачів вищої школи, які формуються освітньо-професійними програмами підготовки, мають бути здатності, які відображають самоорганізаційні навички фахівця: - критично мислити, адаптуватися до суспільних змін і викликів; використовувати набутий особистісно-професійний досвід для розв'язання фахових і життєвих ситуацій; - здатність до рефлексії власного освітнього і професійного досвіду; критичної оцінки результатів діяльності; готовність до постійного саморозвитку і самовдосконалення; - здатність до особистої відповідальності й автономної ініціативи в складних непередбачуваних ситуаціях, у професійних або еквівалентних контекстах, пов'язаних із освітою" [11, с. 108].

Уміння організувати себе та власну професійну діяльність $€$ основою успішної майбутньої професійної 
діяльності фахівців нової формації до реалізації здоров'язбережувальних технологій, запорукою його особистісного зростання.

Головна мета самоорганізації особистості полягає в тому, щоб максимально використовувати особистісний потенціал, свідомо керувати процесом своєї життєдіяльності, підсилювати й ефективно використовувати внутрішні ресурси та долати зовнішні обставини як у професійній, так і в особистісній сферах, досягати успіху ефективним шляхом [11, с. 110].

Висновки. Обґрунтовано необхідність створення й реалізації цілісного науково-методичного супроводу підготовки майбутніх фахівців до реалізації здоров'язбережувальних технологій, що збагатить і розширить зміст підготовки майбутніх кадрів, поглибить окремі розділи навчальних дисциплін, спрямовані на формування теоретичної і практичної готовності студентів до реалізації здоров'язбережувальних технологій.

Удосконалення структури змісту підготовки майбутніх фахівців до реалізації здоров'язбережувальних технологій дало змогу посилити ефективність фрахової підготовки майбутніх спеціалістів до застосування новітніх технологій, змістити акцент зі значущості процесів засвоєння інформації студентами молодших курсів на самостійний пошук її студентами старших курсів, для набуття професійної компетентності.

Доведено, що завдяки безперервному зв'язку між окремими етапами навчання та ступенями освіти, осмисленням наявних знань і підкріпленням їх новими, узгодженістю кожного компонента освіти, студент стає активним об'єктом педагогічної дії, отримує змогу поліпшити рівень самостійності, пізнати себе як суб'єкта життєдіяльності, експериментувати у сфері здоров'язбереження, саморозвиватися як професіонал, який уміє оперувати здоров'язбережувальними технологіями.

3'ясовано, що найважливішою складовою професійної підготовки студентів закладів вищої освіти є практика, завдання, зміст, організаційні форми, методичне забезпечення якої повинні сприяти оволодінню студентом основами професійних умінь, навичок у єдності фрахівця високої кваліфікації, а також допомогти йому у фрормуванні професійно значущих якостей його особистості. Практика є потужним інструментом поліпшення їхнього фрахового становлення, допомагає реалізувати потребу в самоосвіті, створює умови для ефективної праці майбутніх фахівців, відбору доцільних методів і прийомів педагогічного впливу; актуалізує пізнавальні інтереси студентів; нейтралізує фрормалізм у системі оцінювання; стимулює бажання ініціювати, перебувати в пошуку альтернативних варіантів розв'язання стандартних і проблемних ситуацій.

Загальний огляд навчальних програм підготовки майбутніх фрахівців до реалізації здоров'язбережувальних технологій у межах аналізованого напряму засвідчує деяку специфіку змісту навчальних дисциплін циклу професійної підготовки, що зумовлене ресурсами закладів вищої освіти. Зміст загального та професійного циклів навчальних планів підготовки магістрів сформовано 3 урахуванням загальних і спеціальних компетентностей майбутніх фахівців. Практична підготовка майбутніх фрахівців до реалізації здоров'язбережувальних технологій здійснюється у процесі виробничої й науково-дослідницької практик, які характеризуються видовим різноманіттям у вітчизняних закладах вищої освіти.

У статті наголошено, що ефективність здоров'язбережувальних технологій залежить від набору здоров'язбережувальних компетенцій, які допомагають форму- ванню діяльнісної позиції студента в навчально-виховному процесі, розвитку особистісних професійних якостей, здібностей, навичок і знань майбутніх фахівців. Раціональне поєднання самостійних та індивідуальних завдань, застосування опанованих знань та аудиторного практичного досвіду, умінь у процесі розв'язання професійних ситуацій, спрямованих на реалізацію здоров'язбережувальних технологій, сприяють розвиткові творчого мислення, формуванню в майбутніх фахівців потреби у самоосвіті, самопізнанні та прагнення до самовиховання.

Список використаних джерел

1. Батечко Н. Сучасні підходи до формування змісту підготовки майбутніх викладачів вищої школи в умовах магістратури / Н. Батечко // Педагогічний процес: теорія і практика. - 2013. - Вип. 4. - С. 5-20.

2. Гринченко І. Сучасні напрями впровадження інновацій в професійну підготовку майбутніх учителів фізичної культури [ / І. Гринченко // Вісн. Житомир держ. ун-ту ім. I. Франка - Серія: Педагогічні науки / Житомир. держ. ун-т ім. І. Франка. - Житомир : вид-во ЖДУ ім. І. Франка, 2012. Вип. 64. - С. 103-107.

3. Дольнікова Л. Організаційно-педагогічні формування системи інтегрованих знань студентів як передумови підвищення їх фахової компетенції / Л. Дольнікова, Л. Цубов // Вісн. нац. ун-ту "Львівська політехніка". 2012. - № 739. - С. 273-278.

4. Дубасенюк О. Інноваційні навчальні технології - основа модернізації університетської освіти / О. Дубасенюк // Освітні інноваційні технології у процесі викладання навчальних дисциплін: зб. наук.-метод. пр. / за ред. О. Дубасенюк. - Житомир : ЖДУ, 2004. - С. 3-14.

5. Однолеток Т. Професійна підготовка майбутніх учителів фізичної культури як педагогічна проблема / Т. Однолеток, М. Лянной // Педагогіка, психологія та медико-біологічні проблеми фізичного виховання і спорту : наук. журн. / за ред. С. С. Єрмакова. - Х. : ХДАДМ (ХХПІ), 2009. № 9. - С. 107-109.

6. Остапенко Г. Структурні компоненти готовності майбутніх учителів фізичної культури до організації здоров'язбережувального навчальновиховного середовища загальноосвітньої школи / Г. Остапенко, О. Циганок, С. Жестков // Вісн. Запоріз. нац. ун-ту. - Серія: Фізичне виховання і спорт. - 2012. - № 1 (7). - С. 78-85

7. Сбруєва А. А. Порівняльна педагогіка : навч. посіб. / А. А. Сбруєва. К. : Суми: Ред.-вид. відділ СДПУ, 1999.

8. Словник української мови : у 11 т. - К. : Наук. думка, 1972. - Т. 3

9. Клепко С. Інтеграція і поліморфізм знання у вищій освіті / С. Клепко // Філософрія освіти. Наук. часопис. - 2005. - № 2. - С. 20-36.

10. Красовська О. Принципи відбору та структурування змісту професійної підготовки майбутніх учителів початкової школи у галузі мистецької освіти засобами інноваційних технологій / О. Красовська // Оновлення змісту, форм та методів навчання і виховання в закладах освіти. - 2014 . - Вип. 9. - С. 37-40.

11. Мирончук $\mathrm{H}$. Наступність змісту практичної підготовки майбутніх учителів у ВНЗ / Н Мирончук Н. // Нові технології навчання: наук.-метод. зб. / Ін-т інновац. технолог. і змісту освіти Міністерства освіти і науки України. - К., 2014. - Вип. 81. - С. 106-110.

12. Ніколаєнко С. Проблема структури професійно-педагогічної культури вчителя / С. Ніколаєнко, С. Ніколаєнко // Світогляд - Філософрія Релігія. - 2013. - Вип. 4. - С. 277-285.

13. Український педагогічний словник / за ред. С. У. Гончаренка. - К. : Либідь, 1997.

14. Шмелев В. Оптимизация процесса подготовки студентов института физической культуры к профессиональной деятельности на основе модели специалиста: автореферат диссертации на соискание ученой степени канд. пед. наук : спец. 13.00.04 / В. Е. Шмелев. - СПб., 2002.

\section{References}

1. Batechko N. Suchasni pidxody' do formuvannya zmistu pidgotovky' majbutnix vy'kladachiv vy'shhoyi shkoly' v umovax magistratury' / N. Batechko // Pedagogichny'j proces: teoriya i prakty'ka. - 2013. - Vy'p. 4. - S. 5-20.

2. Gry'nchenko I. Suchasni napryamy' vprovadzhennya innovacij v profesijnu pidgotovku majbutnix uchy'teliv fizy'chnoyi kul'tury' [ / I. Gry'nchenko // Visny'k Zhy'tomy'rs'kogo derzhavnogo universy'tetu im. I. Franka. Seriya: Pedagogichni nauky' / Zhy'tomy'r. derzh. un-t im. I. Franka. - Zhy'tomy'r vy'd-vo ZhDU im. I. Franka, 2012. - Vy'p. 64. - S. 103-107.

3. Dol'nikova L. Organizacijno-pedagogichni formuvannya sy'stemy' integrovany'x znan' studentiv yak peredumovy' pidvy'shhennya yix faxovoyi kompetenciyi / L. Dol'nikova, L. Czubov // Visny'k nacional'nogo un-tu "L'viv politexnika". - 2012. - № 739. - S. 273-278.

4. Dubasenyuk O. Innovacijni navchal'ni texnologiyi - osnova modernizaciyi universy'tets'koyi osvity' / O. Dubasenyuk // Osvitni innovacijni texnologiyi u procesi vy'kladannya navchal'ny'x dy'scy'plin : zb. nauk.-metod. pr. / za red. O. Dubasenyuk. - Zhy'tomy'r : ZhDU, 2004. - S. 3-14.

5 Odnoletok T. Profesijna pidgotovka majbutnix uchy'teliv fizy'chnoyi kul'tury' yak pedagogichna problema / T. Odnoletok, M. Lyannoj // Pedagogika, psy'xologiya ta medy'ko-biologichni problemy' fizy'chnogo vy'xovannya i sportu : naukovy'j zhurnal / za red. prof. S. S. Yermakova. - Xarkiv : XDADM (XXPI), 2009 - № 9. - S. 107-109. 
6. Ostapenko G. Strukturni komponenty' gotovnosti majbutnix uchy'teliv fizy'chnoyi kul'tury' do organizaciyi zdorov'yazberezhuval'nogo navchal'novy'xovnogo seredovy'shha zagal'noosvitn'oyi shkoly' / G. Ostapenko, O. Cy'ganok, S. Zhestkov // Visny'k Zaporiz'kogo nacional'nogo un-tu. - Seriya: Fizy'chne vy'xovannya i sport. - 2012. - № 1 (7). - S. 78-85.

7. Sbruyeva A. A. [Porivnyal'na pedagogika] / Navchal'ny'j posibny'k. -K. Sumy': Redakcijno-vy'davny'chy'j viddil SDPU, 1999.

8. Slovny'k ukrayins'koyi movy' : v 11 tomax. - K. : Naukova dumka, 1972. - T. 3.

9. Klepko S. Integraciya i polimorfizm znannya u vy'shhij osviti / S. Klepko // Filosofiya osvity'. Naukovy'j chasopy's. - 2005. - № 2. - S. 20-36.

10. Krasovs'ka O. Pry'ncy'py' vidboru ta strukturuvannya zmistu profesijnoyi pidgotovky' majbutnix uchy'teliv pochatkovoyi shkoly' u galuzi my'stecz'koyi osvity' zasobamy' innovacijny'x texnologij / O. Krasovs'ka // Onovlennya zmistu, form ta metodiv navchannya i vy'xovannya $\vee$ zakladax osvity'. - 2014. - Vy'p. 9. - S. 37-40.
11. My'ronchuk N. Nastupnist' zmistu prakty'chnoyi pidgotovky' majbutnix uchy'teliv u VNZ / N My'ronchuk N. // Novi texnologiyi navchannya: nauk.metod. zb. / In-t innovacz. texnolog. i zmistu osvity' Ministerstva osvity' i nauky' Ukrayiny'. - K., 2014. - Vy'p. 81. - S. 106-110.

12. Nikolayenko S. Problema struktury' profesijno-pedagogichnoyi kul'tury' vchy'telya / S. Nikolayenko, S. Nikolayenko // Svitoglyad - Filosofiya Religiya. - 2013. - Vy'p. 4. - S. 277-285.

13. Ukrayins'ky'j pedagogichny'j slovny'k / za red. S. U. Goncharenko. - K. : Ly'bid', 1997.

14. Shmelev V. Optimizatsiya protsessa podgotovki studentov instituta fizicheskoy kulturyi $k$ professionalnoy deyatelnosti na osnove modeli spetsialista : avtoreferat dissertatsii na soiskanie uchenoy stepeni kand. ped. nauk : spets. 13.00.04 "Teoriya i metodika fizicheskogo vospitaniya, sportivnoy trenirovki, ozdorovitelnoy i adaptivnoy fizicheskoy kulturyi" , V. E. Shmelev. - Sankt-Peterburg, 2002.

Надійшла до редколегії 24.01.20

I. Usatova, PhD, Senior Lecturer,

V. Tkachenko, PhD, Associated Professor,

A. Vedmediuk, PhD, Associated Professor,

Bohdan Khmelnytsky National University of Cherkasy, Cherkasy, Ukraine.

\title{
BULUILDING CONTENT TRAINING TECHNOLOGIES OF PREPARING FUTURE SPECIALISTS FOR THE IMPLEMENTATION OF HEALTHCARE SAVING TECHNOLOGIES
}

\begin{abstract}
In the article on the basis of scientific and pedagogical sources the ways of perfection of the system of professional education with the purpose of preparing the future specialist for the practical realization of the idea of health saving of the nation at all stages of educational activity are analyzed and solved; the general structure of the system of quality assurance of education at the higher educational institution level is substantiated; determined the effective use of didactic principles; new approaches to the development of content, forms and methods of professional training of specialists in the new formation; the content of professional training of future specialists is investigated, covering the set of knowledge, skills and abilities, possession of which enables to work for the chosen type of profession; The set of principles, functions and factors that influence the content of the training is outlined in the curricula and programs of higher education institutions. An analysis of the structure of training of future specialists in higher education institutions is presented, which predicts mastery of a complex of professional and personal components of a future specialist. The peculiarities of preparation of future specialists for the implementation of health-saving technologies in the educational programs offered by educational establishments have been clarified. Types of variety of industrial and research practices are shown, forms and methods of teaching are named.

The content of the professional training of future specialists is characterized, the prerequisites for creating the concept of forming the future specialists' willingness to carry out innovative activity are outlined; conditions of effective use of health-saving technologies are formulated, essential characteristics and stages of preparation of future specialists in educational establishments are explained; The basic provisions are substantiated, the observance of which ensures the training of new formation specialists for the implementation of health-saving technologies. It is noted that the capacity for self-organization is the basis of successful professional activity of the future specialist and the educational disciplines of the programs of preparation of domestic higher education institutions are observed, the study of which contributes to the formation of the competence of selforganization. The essence of the problem under consideration and the technology of its solution are revealed.
\end{abstract}

Keywords: future specialist, general principles, health-saving technologies.

УДК 378:37:331.548

DOI: https://doi.org/10.17721/2415-3699.2020.12.16

Л. Левицька, канд. пед. наук, доц. Київський національний університет імені Тараса Шевченка, Київ

\section{ГЕНЕЗА ФОРМУВАННЯ ЦІННІСНИХ ОРІЕНТАЦІЙ СТУДЕНТСЬКОї МОЛОДІ В ІСТОРІЇ ВІТЧИЗНЯНОї ПЕДАГОГІЧНОї ДУМКИ (XX - ПОЧАТОК XXI СТОЛІТТЯ)}

Розглянуто історико-педагогічний аспект генези формування ціннісних орієнтацій студентської молоді в закладах вищої освіти України XX - початку XXI cm. Охарактеризовано передумови посилення тенденцій розвитку ідей та накопичення досвіду формування ціннісних орієнтацій у закладах вищої освіти України в XX- початку XXI ст. Розкрито сутність дефініції "ціннісні орієнтації". Розглянуто зміни, що відбулися в ціннісних орієнтаціях молоді в Україні. Систематизовано теоретичні ідеї й узагальнено досвід формування ціннісних орієнтацій студентської молоді в закладах вищої освіти України (XX - початок XXI cm.) і на цій основі обґрунтовано перспективи подальшого формування ціннісних орієнтацій студентської молоді в ЗВО України.

Ключові слова: цінності, ціннісні орієнтації, формування ціннісних орієнтацій, студентська молодь, заклади вищої ocsimu (3BO).

Постановка проблеми. Актуалізують означену проблему кризові реалії сьогоднішнього буття, невизначеність молоді у прийдешньому, різні теоретичні підходи до розгляду проблеми цінностей, реформування вищої освіти, зміна статусу культури й характеру людської діяльності та багато інших чинників. Формування системи цінностей молодих людей, їхнє трансформування в ціннісні орієнтації, визначені як пріоритетні завдання сучасних закладів вищої освіти, що задекларовано Законами України "Про освіту" і "Про вищу освіту", Національною стратегією розвитку освіти в Україні на 2012-2021 рр. та ін.

У формуванні особистості майбутнього фахівця ціннісні орієнтації визначають напрям і рівень активності та суттєво впливають на його професійні якості. Проблема ціннісних орієнтацій є однією з пріоритетних у сучасній науці. Зростаюча необхідність формування моральності та громадянської спрямованості особистості у процесі професійної підготовки молоді зумовлює підвищення наукового інтересу до вивчення закономірностей становлення ціннісних професійних орієнтацій студентської молоді.

Аналіз останніх досліджень і публікацій. На необхідність формування у студентської молоді ціннісних орієнтацій наголошувалось багатьма дослідниками (О. Антоновський, Т. Артімова, В. Желанова, Ю. Костєва, І. Марценюк, О. Сухомлинська та ін. 